Citation: T. Kardel (2021) Nicolaus Steno on Solutes and Solvents in Time-Related Structural Changes of Muscles, Fossils, Landscapes and Crystals, his Galilean Heritage. Substantia 5(1) Suppl.: 43-57. doi: 10.36253/Substantia-1277

Copyright: (c) 2021 T. Kardel. This is an open access, peer-reviewed article published by Firenze University Press (http://www.fupress.com/substantia) and distributed under the terms of the Creative Commons Attribution License, which permits unrestricted use, distribution, and reproduction in any medium, provided the original author and source are credited.

Data Availability Statement: All relevant data are within the paper and its Supporting Information files.

Competing Interests: The Author(s) declare(s) no conflict of interest.

\section{Nicolaus Steno on Solutes and Solvents in Time- Related Structural Changes of Muscles, Fossils, Landscapes and Crystals, his Galilean Heritage ${ }^{1}$}

\author{
Troels Kardel \\ D.Med.Sci.(CPH), retired general physician and lecturer in internal medicine and general \\ practice. DK-2840 Holte, Denmark \\ E-mail: kardel@dadlnet.dk
}

\begin{abstract}
In Part One of the Specimen of Elements of Myology, a book in three parts published in Florence 1667, Nicolaus Steno described the changes taking place between muscle relaxation and contraction in a two-stage geometrical model based on anatomical observations in man and animals. The 'new myology' was rejected by G.A. Borelli in 1680 and outright ridiculed by J. Bernoulli in 1694. The anatomical correctness and predictive value was rightfully acknowledged only towards the Millennium. In Part Two, the Canis ..., Steno gave a detailed anatomical description of a giant shark's head with focus on the likeness of its teeth and the so-called tongue stones, or "glossopetrae", dug from the ground. Steno conjectured that remnants from sharks living in the past had become fossils due to chemical processes through interaction with the surrounding sediments at the bottom of the sea, presuming that the finding areas had been sea-covered. From studies in Part Three of reproductive organs in mammals, viviparous ray-fish and shark, he concluded that the so-called female testicles in women and mammals are analogous with ovaries of oviparous animals and should therefore be named accordingly. Two years later in the Prodromus De Solido intra Solidum, Steno described the transformation over time of sedimentary landscapes in Tuscany, and how crystals grow by accretion to the surface of entities derived from limpid sea-water or freshwater in caves. These are studies of time-related transformations of solids in organic and inorganic materials. However, such processes could not be documented by visual observation, since changes go too quickly in muscles, in the case of the landscapes because the transformations took place in the past. Thus, Steno and contemporaries put forward hypotheses on such hidden processes that were only gradually corroborated when fitting into a cluster of evidence. His considerations on crystal growth may have been triggered by an interest as a physician to know how saliva, gall and kidney stones are formed. Likewise, considerations on sharks' replacement of their teeth could extend knowledge on dentition to bring a better cure for those who complain of being toothless. He emphasized the importance of mathematical methods to describe processes in the human body and cited from Galileo, Discourse on Bodies in Water (1612), in which physics outweighs Aristotelian rules to explain the interaction of solids and solvents. Likewise, Steno's 'New Myology' was a showdown against an Aristotelean physical dogma from Physics VII: everything which moves is moved by another, which excluded fibre shortening in muscles and blinded researchers on muscle contraction for generations after Steno.
\end{abstract}

\footnotetext{
${ }^{1}$ This paper was written during the height of the Covid-19 epidemics in 2020 based on impressions from seminars in 2019 in Copenhagen, San Francisco, and most of all, the conference Galilean Foundation for a Solid Earth in Florence. All references are numbered in square brackets and listed at the end of the paper.
} 
Keywords: Nicolaus Steno, History of Geology, History of Biology, Geometrical Models.

\section{INTRODUCTION}

How well then everything fits together!

How unanimously they come together in agreement. ${ }^{2}$

This paper contributes reflections on Steno's 'New Myology', published 1667 in Specimen of Elements of Myology [2] and draws parallels to the Prodromus to a Dissertation on a Solid Naturally Contained Within a Solid [3] that followed only two years later, and to other writings showing his interest in body-liquids in biology and the solute-solvent relation in geology. It will be shown that Steno took an anti-Aristotelean stand in his biological as well as in his geological research.

In his research on muscle Steno added a time relation to structural transformations making observations measurable in a meaningful way as devised by Galileo already recognized in his time. ${ }^{3}$ As a student in Copenhagen Steno excerpted text from Galileo's, Sidereus Nuncius (1610), in the CHAOS-Manuscript (1659) ([4] pp. 301-302). In the Prodromus ([1] pp. 169, 802) he quoted essentials from Galileo's Discourse on Bodies in Water (1612) [5] in which Galileo expressed a critical position to Aristotelian explanations of physical phenomena. Along the same line, Steno's 'New Myology' was a showdown against an Aristotelean physical dogma that precluded fibre shortening in muscles as earlier researched and described in the following section ([17] p. 40).

\section{SPECIMEN OF ELEMENTS OF MYOLOGY, A BOOK IN THREE PARTS.}

Part one, the Specimen, is entitled as the whole book. In the introduction the author expressed that he:

wished to demonstrate in this dissertation that unless myology becomes a part of mathematics, the parts of muscles cannot be distinctly designated, nor their move-

\footnotetext{
2 'Qvam bene itaqve conveniunt omnia! Qvam unanimi consensu inter se conspirant!', quotation p. 726 in T. Kardel, P. Maquet, eds., Nicolaus Steno, Biography and Original Papers of a 17th Century Scientist, $2^{\text {nd }}$ edition, Heidelberg, Springer, 2018 https://doi.org/10.1007/978-3-66255047-2_4 ([1], p. 726).

3 'When Cardinal Leopold sent Steno's Myology to Michel Angelo Ricci, the Roman erudite thanked him on May 30, 1667 and said he was enthused by the zeal, the gift of observation, and the genius of the Danish researcher and praised his endeavours in the spirit of Galileo' ([1], p. 167).
}

ment successfully studied. And why should we not give to the muscles what astronomers give to the sky, what geographers to the earth, and, to take an example from microcosm, what writers on optics concede to the eyes. ([1], pp. $187,651)$

Steno leans on a text by Galileo, Il saggiatore (1623)

Philosophy is written in this grand book, the universe, which stands continually open to our gaze. But the book cannot be understood unless one first learns to comprehend the language and read the letters in which it is composed. It is written in the language of mathematics, and its characters are triangles, circles and others geometric figures without which it is humanly impossible to understand a single word of it; without these, one wanders about in a dark labyrinth. ([5], p. 207)

In the Specimen, a geometrical analysis of the muscle contraction is based on anatomical dissections in animals and humans with the inner structure illustrated by three wood-block prints, displayed as when cut along the length of the muscle from tendon to tendon. Just one cut in a leg of a rabbit was enough for Steno to realize the shortcomings of the ancient system and then make a three-dimensional geometrical model in two stages, relaxation and contraction (Fig. 1).

Two elements were essential to make a model of muscle contraction, first the feather-like, or pennate structure of skeletal muscle. He saw it two-dimensionally in a cut along the fibers and visualized it as a parallelepiped in three dimensions in three wood-block prints ([1], pp. 677-686) altogether specified from anatomical dissections in 44 Definitions ([1], pp. 654-664). The functional properties as the result of shortening of muscle fibres was detailed in five Suppositions ([1], pp. 664). A geometric deduction in six Lemmas, help sentences, allowed him in the Proposition to conclude that muscles in action make a swelling of muscle even without an increased volume. Therefore, the swelling as seen and felt during contraction is not an argument for volume increase by 'animal spirits' as had been held since antiquity ([1], p. 653). He rejected the so-called 'animal spirits' as an alleged instrument of action within the body when an acting agent was in demand and shunned speculative stereotypes. Early he wrote, "Reasoning deprived of the work of the senses did not find the paths carrying the saliva into the mouth" ([1], p. 428).

Considering the contraction process, Steno mentions some areas where knowledge on muscle was lacking, 

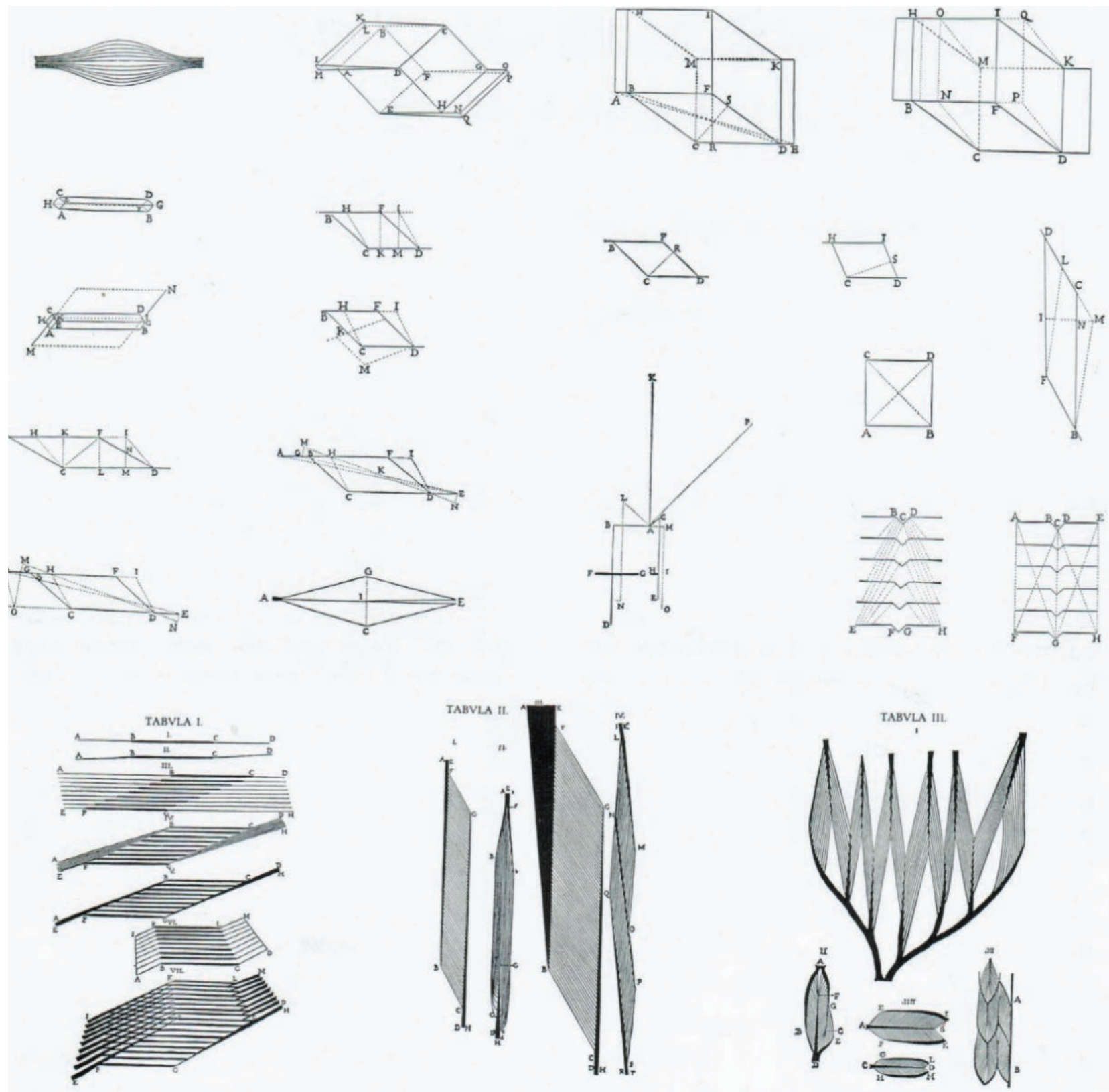

Fotomontage af Niels Stensens illustrationer i Elementorum Myologiae Specimen *.

Figure 1. Illustrations brought together from the Specimen of Myology by Harald Moe ([6], p. 100). The upper left sketch shows what Steno calls the ancient structure of muscle, and thereafter what he proposes as the new structure of muscle. Then sketches of a model in relaxation (solid lines) and action (stippled lines), when fibres of the muscle shorten. In the lower row, three wood-block prints show: Tabula I, the inner structure of the typical feather-like, or pennate, muscle with the lower drawings in true perspective; Tabula II, the inner structure of gastrocnemius, biceps brachii, semimembranosus and semitendinosus muscles; Tabula III shows the deltoid and masseter muscles, all from dissections in humans, and muscles from claw of lobster (abductor and adductor) and from fish. In the lower row, the anatomical base for Steno's model of muscle contraction as drawn in the functional sketches above.

among them 'What is the movement of the fluid?' ([1], p. 695). This is even today an object of investigation being pressure dependent.
Steno developed his muscle theory in the early 1660's during doctoral studies on glands in Leiden. He was at the same time trained in brain anatomy by Frans dele Boë 


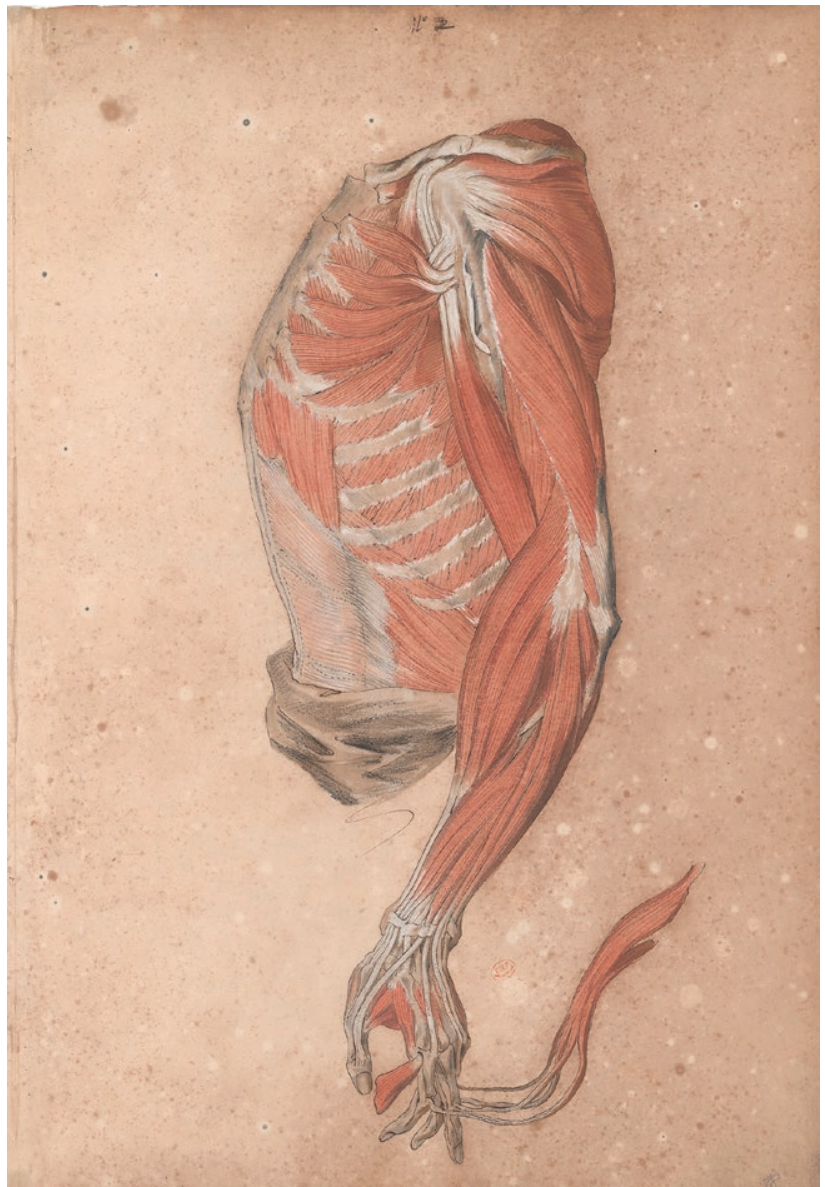

Figure 2. Muscles and tendons of the human shoulder and arm as described by Johannes Van Horne and illustrated in colour by Marten Sagemolen in Leiden, appr. 1660 [7].

Sylvius and in anatomy of the muscles by Johannes Van Horne. The magnificent atlas of the human muscle system by the latter with colour drawings by Marten Sagemolen [7] was ready for print but went in oblivion after Van Horne's death in 1670. The drawings were only recently rediscovered to reveal a masterpiece in colour (Fig. 2). ${ }^{4}$

Optimally trained for the task Steno realized that the ancient system of the brain's motor control by 'animal spirits' carried through hollow nerves to enact muscular contraction by inflation as described by Descartes 1662 in the posthumous, Treaty on $\mathrm{Man}^{5}$ [8] lacked ana-

\footnotetext{
${ }^{4}$ J.-F. Vincent, C. Perrot. Johannes Van Horne and Marten Sagemolen's myology. - 31 Aug. 2016. Trad. Oct. 2016 http://www.biusante.parisdescartes.fr/ressources/pdf/van-horne en.pdf

${ }^{5} \mathrm{R}$. Des Cartes, De Homine figuris et latinitate donatus a Florentio Schuyl, Leiden, Moyardus and Leffen, 1662. Title page with the translator's dedication to the erudite King of Denmark and Norway in (10) T. Kardel, Steno - Life, Science, Philosophy. Acta historica scientiarum naturalium et medicinalium, 44, Copenhagen 1994, p. 27 (11)
}

tomical correlates. Alongside, Jan Swammerdam, a fellow student and friend of Steno's, made experiments that showed no volume increase during contraction in frog muscles kept within a restricted space. Swammerdam's results countered muscle contraction by inflation but remained unpublished until 1737 [9]. A preliminary version of Steno's myology was published in the Specimen of Observation on Muscles and Glands, in Amsterdam and in Copenhagen, 1664 in which he also emphasized that "the heart is actually a muscle", followed up with a categorical statement on,

What the Substance of the Heart is Not: The heart is no longer a substance of its own kind and, therefore, it is neither the seat of a certain substance like fire, innate heat, the soul, nor the generator of a certain humour, like the blood, nor the producer of some spirits, e.g. vital spirits. ([1], p. 565)

In the Discourse on the Anatomy of the Brain held in Paris 1665 and published four years later, Steno distanced himself from Descartes' and Willis's speculative approaches to brain anatomy. When in Paris, Steno demonstrated the "new myology" as evidenced by the Graindorge letters to Huët [10]. He showed the new system for travelling English scientists at their sojourn in Montpellier. William Croone had also published a book on muscle contraction in 1664. Unlike Steno, Croone explained and illustrated the contraction of muscle based on inflation like Descartes. On their encounter Nayler concludes: '... arguments adduced by Steno seem to have had no impact on Croone's thinking' [11]. For a long time Croone was the influential secretary of the Royal Society. He favoured Borelli's work in 1680 and never accepted fibre shortening [12]. In Wilson's account: 'Poor Croone must have felt rather crushed when he finished reading this critical discussion by Steno. Those features of his theory which were not wrong were at best speculative' [13].

Met by interest, Steno's work on muscle received limited early support. Yet, with recommendations by his mentor Thomas Bartholin and his benefactor in Paris, Melchisédek Thévenot, Steno was well received in Florence, as remarked in a recently recovered letter by Prince Leopold, the Principal of the Cimento Academy:

[We recently received two guests among whom] the Danish Anatomist Mr. Stenone, young of age but distinguished in his profession with every sort of erudition, and a good geometrician which will greatly help him in his profession, and the true type of modesty. ${ }^{6}$

${ }^{6}$ Leopoldo de' Medici: Letter in Italian, dated 1666 (April 27?) in Firenze. Royal Danish Library, Manuscript Collection, Shelf Mark: Acc. 
Pendulums, éc. All which, whilt the Reäder is confidering, thé Author tells him, that he is making ready his other Books concerning the Motions of Animals.

IV. NIC. STENONIS MUSCULI DESCRIPTIO

GEOMETRICA, Florentia in 4 . Ann. 1667.

The Author of this Book declareth, that his delign in compofing it was to fhew, that in a Mufcle neither the Parts of it can be diftinetly named, nor its Motion duly conlidered, unlefs the Doctrine thereof become a part of the Matbematicks. And he is of opinion, that there is no other caufe of the many Errors, which fpoil the Hiftory concerning the Husmane Body, than that Anatomy hath hitherto difdain'd the Lares of the Mathematicles: And therefore inviteth thofe that are fudious in that part of Philofophy, to confider, that our Body is an Engine made up of a thotifand fubordinate Engines, whofe true knowledge whoever thinks that it can be inveltigated without Mathematical afiiftance, muft alio think, that there is matte: without Extenfion, and Body withoit Figure.

Hereupon he hews, that the very $F$ atrick of the $M u f c l e s$ impofeth a kirid of neceffity upon confidering Writers to expiicate them Matbematically: Ii conformity whereunto, he preterds to have found, that in every Mufcle there is one Parallelepipea of Flefin, ard two Tetragonal Prifims of Tendons, defining a Mufcle to ise a Bodv compofed of divers Series's, or ranks of Fibres, equal, like, and paraliel among themfeives, and fo immediately placed upon one another, tiat whole Ranks are congruous to whole Ranks. Here he explains the Dimenfions of a Mufcle, its Contraction and Strength; and adds, that the $" f t$ of this rew difcovery of the ftructure of the $M u f c l e s$, is to demonftrate, That they may fivell in their Contraction without the Acceftion of new Mlatter.

He fubjoins a Letter to Mfonfieur $T$ luevenot, in which, among other things, he alledges feveral Experiments, to hew, that the motion of the Heart is like the motion of Mufcles; ard anfivers thofe who pretend, that the true Fabrick of the Heart hath already been obferved kcretefore; and thofe likewife who think, that thefe rew Obicrvations of the Kufcles are ur.certain, concluding this Subject with an enumeration of the Particulars,

Figure 3. Part of the review of the Specimen of Elements of Myology published in the Transactions of the Royal Society of London, in $1667 / 68$ [14].

But he also anticipated criticism as reflected in the Specimen:

I can imagine that a number of people will stop after the introductory remarks and decide that this new muscle structure is just a new chimera. But I hope that these people will be kind enough to wait until they have read the entire dissertation before expressing their opinion. They will indeed realize that I follow the track of nature closely, presenting nothing unnecessary. ([1], p. 653)

Unmistakably, Steno's address was intended for Borelli.

The Specimen was reviewed in London in the year of publication [14] (Fig. 3).

The reviewer quoted that in a muscle the motion cannot be described without the use of mathematics, and that the same applies to other bodily functions and mentions that a muscle model shaped like a parallelepiped may swell in contraction without the accession of new

2019/54. http://www5.kb.dk/manus/vmanus/2011/dec/ha/object254119/ $\mathrm{da} /$. The letter was offered for sale by www.historyforsale.com and found there in a google-search on checking the year when Prince Leopold became a cardinal. The letter was purchased via www.amazon.com and donated to the Royal National Library in Copenhagen in 2019. matter. Thomas Willis illustrated the pennate structure of skeletal muscle like Steno; Willis adhered, however, to the idea of shortening of muscle by expansion from a kind of explosion [15]. Except for Richard Lower, Willis's assistant, Steno did not obtain British support for the new myology. Soon after in Leiden Steno's former teachers, Sylvius and Van Horne, died. The 'new myology' was recorded in Steno's homeland by Thomas Bartholin with an illustration in Anatomia Renovata, 1673 ([16], p. 290). But no one at home took up valid research on this topic. When therefore the 'new myology' was rejected by eminent scientists and had no supporters, 'the ancient system' got the upper hand for one more century.

The main objectors were Borelli (De Motu Animalium, 1680), Bernoulli (De Motu Musculorum, 1694), Boerhaave (Praelectiones, 1743) and von Haller (Elementa Physiologiae, 1762), the latter observed muscle fibres shortening by microscopy but objected against the pennate structure of muscle [17]. By the end of 18th century Steno's myology disappeared from the scientific literature.

Quotations from Steno and Borelli are like a protracted dialogue on two chief muscular systems [18, 19]. Steno presented his Systema novum musculi in Florence, 1667 [2]. Borelli rejected the new and defended the ancient system in his De motu animalium/On the Motion of Animals, in Rome, 1680 [20]:

On the structure of skeletal muscles:

S: I represent a muscle as a collection of motor fibers arranged so that the flesh in the middle forms an oblique parallelepiped and the tendons form two opposite tetragonal prisms. $(1$, p. 653$)$

B: One must conceive the muscular fibres as a series of small machines of porous or rhomboidal shape like a chain made of rhombs of filaments. ([20], p. 119)

Such single muscles are not seen normally and do not act in the way those famous authors think they do. ([20], p. 13)

On contraction:

S: When a muscle contracts, its different motor fibres shorten. ([1], p. 690)

B: Muscles do not contract by condensing the length of their fibres and bringing closer together their extremities, but their hardness and tightening results from swelling. ([20], p. 217)

On the relation between heart and skeletal muscles:

S: The structure of the motor fiber in the heart and in the muscle is the same: thus the phenomena of movement in the motor fiber which are manifest to our senses and are seen in the muscle are the same in the heart. ([1], p. 690) 
B: The first and indirect cause of the motion of the heart seems to be different from that of the movement of the muscles of the limbs. ([20], p. 282)

On the action of the heart:

S: In a muscle as well as in the heart there is to be observed one and the same action, that is the contraction of the fleshy part. When the fibres of the heart are shortened ... they raise the bottom a little towards the basis and consequently the heart becomes shorter and also rounder. ([1], p. 566)

B: The fibres of the heart are not aimed by Nature at pulling and bringing their extremities closer together. In contracting the fibres swell and decrease the cavity. In so doing they squeeze out the blood in it like a press. ([20], p. 250)

A dialogue along these lines must have taken place between Steno and Borelli in 1666 when Steno was preparing the Specimen and before Borelli left Florence for good. ([20], pp. 237-240)

In a still unpublished thesis from 1993 on the history of muscle contraction in the $17^{\text {th }}$ century Margaret A. Nayler concludes on Borelli:

\begin{abstract}
Although microscopic observations were doubtfully supportive of a compartmentalized muscle fibre, they were not conclusive, and the fact that working models could be constructed to demonstrate that inflated bladders could lift large weights doubtless added to the probability that Borelli's mechanism offered an acceptable explanation. How this mechanism could explain muscle contracting strongly without a change in length, or contracting with variable strength, given the apparently tenuous link between the proposed chemical reaction and the 'force' developed, are just some of the issues which Borelli failed to explore [11].
\end{abstract}

The pennate muscle structure was practically forgotten and only rediscovered in 1981 by P. W. Brand et al., American orthopaedic surgeons, when making anatomical dissections to improve techniques for tendon repair. (21) Anatomical studies were soon made useful in computer simulations of muscle action. While considered to be perhaps his weakest work, arguments were presented to reappraise the Specimen as one of Steno's significant publications and as a significant work in biomechanical science [19].

Evidence in support of Steno's myology was compiled in 1994 from anatomical and overview studies and from computer model investigations (Fig. 4).

In addition, ultrasound recordings (made for other purposes) by Chow and co-authors [23] show changes of fibre length and pennation angle during contraction in human gastrocnemius muscle that match the pennate model proposed by Steno ([1], p. 200). Likewise, the pen-
Anatomical studies, computer model simulations, and biomechanical and historical review articles dealing with the unipennate actuator. Studies that recognize Stensen's contribution are marked with an asterisk [*].

\begin{tabular}{|c|c|c|c|}
\hline \multicolumn{4}{|l|}{ Anatomical studies } \\
\hline Beritoff & 1925 & Hindlimb & Frog \\
\hline Kolb & 1937 & Anterior tibial & Man \\
\hline Rollhăuser and Wendt & 1955 & Gastrocnemius & Cat \\
\hline - Brand et al. & 1981 & Hand & Man \\
\hline - An et al. & 1981 & Elbow & Man \\
\hline Wickiewicz et al. & 1983 & Lower limb & Man \\
\hline Cooney et al. & 1984 & Thumb & Man \\
\hline Huijing & 1984 & Gastrocnemius & Man \\
\hline Lieber and Blevins & 1989 & Hindlimb & Rabbit \\
\hline Heslinga and Huijing & 1990 & Gastrocnemius & \\
\hline Friedrich and Brand & 1990 & Lower limb & Man \\
\hline - Linscheid et al. & 1991 & Hand & Man \\
\hline Spoor et al. & 1992 & Gastrocnemius & Man \\
\hline Lieber et al. & 1992 & Arm & Man \\
\hline \multicolumn{4}{|l|}{ Overview studies } \\
\hline Pfuhl & 1937 & Biomechanics & \\
\hline Benninghoff and Rollhăuser & 1952 & Biomechanics & \\
\hline Gans and Bock & 1965 & Biomechanics & \\
\hline Alexander & 1968 & Biomechanics & \\
\hline$*$ Otten & 1988 & Biomechanics & \\
\hline Zajac & 1989 & Biomechanics & \\
\hline$\cdot$ Kardel & 1990, 1991 & Historical & \\
\hline${ }^{*}$ Huijing & 1991 & Biomechanics & \\
\hline Kaufman et al. & 1991 & Biomechanics & \\
\hline \multicolumn{4}{|l|}{ Model simulations } \\
\hline Huijing and Woittiez & 1984, 1985 & Gastrocnemius & Rat \\
\hline Woittiez et al. & 1984 & Gastrocnemius & Rat \\
\hline - Otten & 1985, 1988 & Hindlimb & Cat \\
\hline - Kaufman et al. & 1989 & \multicolumn{2}{|c|}{ Same data as Woittiez et al. } \\
\hline An et al. & 1989 & Elbow & Man \\
\hline Hoy et al. & 1990 & Lower limb & Man \\
\hline Mai and Lieber & 1990 & Hindlimb & Frog \\
\hline Pandy et al. & 1990 & Lower body & Man \\
\hline Pandy and Zajac & 1991 & Lower body & Man \\
\hline Zuurbier and Huijing & 1992 & Hindlimb & Rat \\
\hline *Van Leeuwen and Spoor & 1992 & Gastrocnemius & Man \\
\hline
\end{tabular}

Figure 4. Anatomical studies, computer model simulations and biomechanical and historical review articles dealing with the unipennate actuator. Studies that recognise Stensen's contribution are marked with an asterisk ([*]: [17], p. 49 and references)

nate structure of the biceps brachii muscle recorded in healthy volunteers by Pappas and co-authors [24], confirms details and proportions of the inner structure in sagittal ultrasound sections of human biceps brachii muscle illustrated by Steno from anatomical studies in meager dead bodies. ([1], p. 202)

Commentary on Part One, the Specimen of Myology: Steno's model is the first display of the inner structure of skeletal muscles and its structural changes in two steps, relaxation and contraction, apt for inclusion in present day's computer simulations of human and animal movements. Through centuries it was considered to be incorrect. Elementorum Myologiae Specimen, the book-title, is a key to the treatise that concerns those specimens of elements (pennate structure and fibre shortening) that are essential to describe myology (the function of muscle).

Opposed by scientists and academies, though not opposed by any church, Steno stood much alone with a new theory on human and animal motion. On leaving science for religion, he left the new myology undefended, to become rejected by Borelli in 1680, and by Bernoulli in 1694 because it violated a physical axiom quoted by the latter, everything which moves is moved by another, from Aristotle, Physics VII. This axiom had blinded Steno's contemporaries and would do so for fellows of 
the Royal Society of London and other eminent scientists way into the $18^{\text {th }}$ century.

An error tag was glued on Steno's myology for much longer.

\section{THE CARCHARODON-HEAD DISSECTED}

In Part Two of the Specimen of Elements of Myolo$g y$, Steno showed in many details the similarity in shape between glossopetrae and the teeth of a giant shark. It brought evidence for the process of fossilization of remnants of sharks that had lived in an ocean of the past. Direct observation is obviously impossible; only signs in solid material remain and can be used in considerations. In muscle contraction, structural changes go too fast for visual observation, while in the case of fossilization, the process is too slow to be observed directly.

He had at hand the so-called glossopetrae or tongue-stones dug from the ground in Malta and at locations in southern Italy and the teeth in the jaws of a huge shark as described and illustrated in the Carcharodon-Head Dissected (1, p. 699). The riddle was to get an idea of the processes taking place in the dead shark's teeth through the action of compounds from the surrounding sediments at the bottom of the sea or after elevation above sea level where 'definite traces of the sea appear in places that are raised several hundreds of feet above sea level' ([1], p. 818).

Observed facts on the fossils and their surrounding soil were set down in 11 arguments under the headline, Historia ([1], p. 718). Here are some of them.

3. In various places, I have seen that the said soil is composed of layers superimposed on each other at an angle to the horizon.

4. I have observed in clayey soil, that these layers, which differ in colour from each other, are split apart in several places, and that all the fissures, which are filled with material of one colour, are almost perpendicular to the layers themselves.

5. In those soils that I have been able to observe up to now, bodies of different kinds have been concealed in the same soil, sometimes in the harder, and sometimes the softer sort. 6. I have observed that the number of these bodies in clay is quite large in the surface but quite small in the soil itself.

Next follow the presumed processes described in six Conjectures.

Conjecture 1, Whether the soil today produces these bodies. Since no bodies seem to be produced anew in harder soil, and since in many regions softer soil probably destroys these bodies, we may suspect not without reason, that soil from which bodies resembling parts of animals are dug does not produce these bodies today.

Conjecture 2, Whether the soil in question has always been of the same firmness.

The soil would not have been firm when the bodies referred to were produced in it.

Conjecture 3, Whether it may have been covered with water.

Since both the configuration of the ground itself and examples from other places [ancient reports on devastating events like earthquakes] indicate that this soil once had another situation, since it seems (Steno refers to Conjecture 2) that the said soil was once less firm, what is to prevent us from ascribing this softness to the waters, and what is more, to believe that the soil, before it changed its site, was covered with waters, whether the waters were exposed to the open air or were covered by the earth's crust?

Conjecture 4, Whether this soil may have been mixed up with water.

That clay and sand are mixed with strongly agitated water is so obvious from the headlong course of torrents through such soils, and from the agitation of waters by the wind, that no further explanation is needed. Nor is it difficult to prove that sand, clay, tufa, and all sorts of solid bodies may be concealed in stagnant water, even the most limpid water.

I have seen my most amiable teacher Borch dissolve a very hard pebble in ordinary water; why then should we not grant to nature what we cannot deny to art?

Conjecture 5, Whether it may be taken for a sediment of water ([1], p. 723).

I shall now make clear the ways in which sediments could have been deposited, so that these matters may in fact be more readily understood.

Steno argues that since water can dissolve solid material, the opposite - that is secretion of solid material from limpid water - may take place. Clear liquids containing solids had been a theme already in Steno's early research on glands and saliva, on tears, on the fluid surrounding the chick in the egg, and it was mentioned six times on amnion fluid in his report on the dissections of various viviparous animals. ([1], pp. 439, 445, 458, 459, $508,636,751)$

Late in Conjecture 5 of the manuscript used for printing the Canis Carchariae, a sign $[+\ldots+]$ tells that a text insertion in a glued-in sheet should be made here apparently a comment written later than the surrounding text (Fig. 5; in the following quote the text from "How well then everything fits together!" to "a sediment from water?"):

Such are the various ways in which solids may be precipitated from a fluid, nay more, fluid from fluid (as may easily be shown of those fluids which form the atmosphere); 
if the layers in our soil have not been formed in all these ways, it is certain that they could have been formed in such ways. But whatever the exact way in which solids are separated from fluids, they appear either in the form of powder, as in the case of metals precipitated from acids, or as coagulated material, whether it be softer, as in blood where it is fibrous, in milk where it is cheesy, in May dew and rain water where it is a viscous sediment or whether it be harder, like tartar in wine, crystals in salt water, and stony crusts in various springs. It is clear from this that crusts could have hardened out of the most transparent waters, crusts of varying consistency, crammed full indeed with minerals of various kinds.

How well then everything fits together! How unanimously they come together in agreement. We find the position of the soil suited to its having been able to hold waters; we know that both powdered soil and the elements of the said soil could have been mixed with the waters; we do not ignore the ways in which they could have both entered and separated from those waters, nay rather we pay close attention to the variety of layers in the soil itself. Why then is it impossible for this soil to have been a sediment from water?

Let those for whom it is not enough go into underground grottos from which stones were once quarried, and they will observe new rock forming in place of the rock that was removed, nay more, they will perceive stone icicles, formed from bodies secreted by atmospheric fluid, hanging from the vaults: these icicles, hollow inside and made of many cylindrical lamellae, receive neither water nor rock from the vaults, this is not only indicated but also proved by the structure of the lamellae.

The reason for the author's outspoken delight expressed here is presumably what was written in the previous paragraph, which deals with the author's preconception of solid precipitations from limpid water. What follows is an explanation of what comes together in agreement with the answer given in the sentences that follow: 'We find ...; We know ...; We do not ignore ...'; concluding: 'Why then is it impossible ...? A question to those holding solid precipitations from limpid water impossible.

Conjecture 6, Whether bodies dug from the ground and resembling parts of animals should be considered parts of animals.

In this, the last conjecture, the overall conclusion of Part Two on the fossilisation of remains of live material is typical for Steno's way of arguing:

Since the bodies resembling parts of animals that are dug from the ground can be considered to be parts of animals, since the shape of tongue stones resembles the teeth of a shark as one egg resembles another, since neither their number nor their position in the earth argues against it, it seems to me that those who assert that large tongue stones are the teeth of a shark are not far from the truth ([1], p. 731).

Hsu has argued that Steno in his six conjectures presented arguments on bodies resembling parts of animals as a plaintiff would do to win a case [25]. I do agree that the inquiry in conjecture 5 resembles arguments in a legal case, but would rather say that Steno in the concluding conjecture 6 made himself the judgment of the 'case'.

The late Martin Brasier in his last paper discussed Steno vis-a-vis a vocal critic of the biological origin of fossil shells, Martin Lister [26]. Brasier pointed out that in a 1673 publication Lister argues in favour of the biological origin of some echinoderm fossils based on taphonomic ${ }^{7}$ criteria as "the earliest known example of taphonomic reasoning in a scientific paper." As commented by Alan Cutler:

Steno had previously published taphonomic observations in both Canis (1667) and De Solido (1669). In Conjectures 1 and 2 (see above), Steno addresses the question of whether shells and tongue stones are preserved animal remains, or if they grew in-situ due to plastic forces in the earth. He uses the quality of preservation of shells including their lack of distortion in hard versus soft ground matrix to argue against in-situ origin. In Conjecture 6, he briefly discusses fragmentation, burial, and diagenesis of fossil remains. In De Solido ([1], pp. 776-777), Steno adds to these ideas, describing different modes of preservation of shells (original material, molds and casts, permineralization), For one specimen he uses his observations to deduce its taphonomic history, "it is possible to conclude with certainty that the shell had been left upon the land by the sea, covered up again by a new deposit and abandoned by the sea" ([1], p. 279).

Though Steno's taphonomic ideas remained undeveloped, they were clearly an important element of his reasoning.

It is worth noticing that Steno made considerations on solid material mixed in water already in his first academic dissertation, On Hot Springs in 1660 ([1], p. 411). Yamada has drawn attention to contemporary considerations by Robert Boyle and Robert Hooke. Moreover, Yamada finds remarks in the CHAOS-manuscript being precursors of Steno's later research [27].

Steno had an additional motive for the study of the nature of teeth, that

ignorance of their nature hitherto has meant that the cure of almost all sicknesses affecting teeth is left only to chance.

\footnotetext{
${ }^{7}$ Taphonomy is the study of how organisms decay and become fossilized.
} 


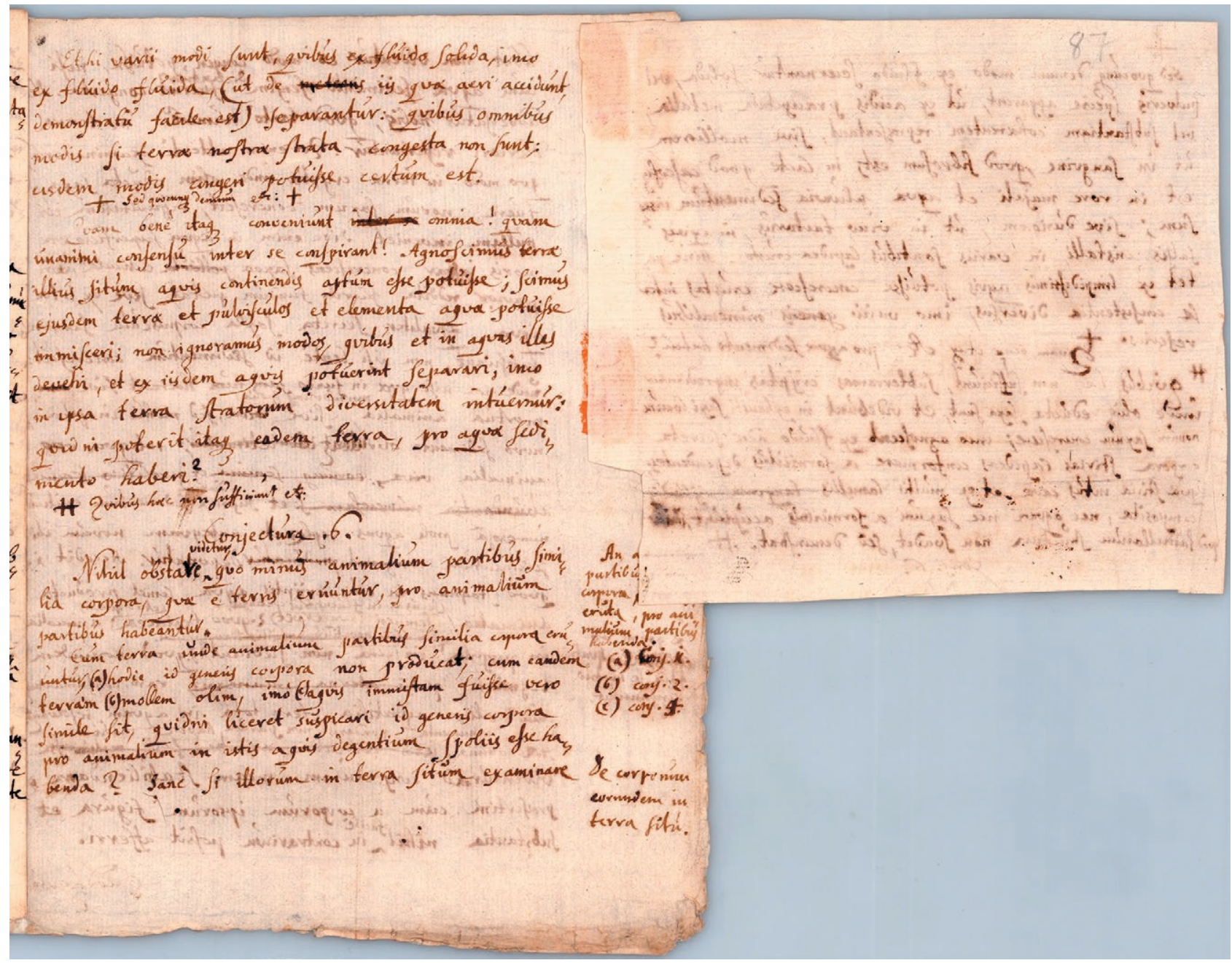

Figure 5. Near the end of Conjecture 5 in the printer's manuscript of Canis carchariae, the sign $+\ldots+$ indicates where to make an insertion from a glued-in sheet. See Fig. 6 for the recto of the glued-in sheet. Illustrations by the Royal National Library, Copenhagen, reproduced with permission.

Who can stop tooth decay once it has begun? Who can lighten their pains? Who can give a clear explanation of the symptoms of teething, or cure it as desired? But if we had a clear idea of their substance, and if we but could make comparisons with other substances, then I do not doubt that we might find a better cure for so many sicknesses, and that the number of those who complain of being toothless would be much less. ([1], p. 717)

Commentary on Part Two: Steno inferred unobservable processes producing structural changes in the teeth of once-living sharks as they became fossils by analogizing particulars that he had observed on the resolution of solid material to and from limpid water. Being merely hypothetical, the live origin of fossils proposed in the Carcharodon-Head Dissected, like the muscle model pro- posed in Part One, came under attack. Both proposals went to oblivion and were rediscovered in later centuries as exemplified by Cutler ([28], pp. 73, 169).

The quote, "it all fits together" [1], seems to indicate the fulfilment of Steno's preconception of solid precipitations from limpid water.

\section{DISSECTION OF A DOGFISH}

The Grand Duke provided another shark for dissection by Steno in Pisa. Historia dissecti piscis ex canum is the third, of the three treatises published jointly in Florence in 1667. The so-called dogfish was a female Scymnus lichia in which Steno found in the oviducts an outer membrane, chorion, and an inner membrane, amnion, 
and bodies, "considered as eggs in which there was not yet signs of a foetus" ([1], pp. 733-738). He determined that it was a viviparous fish, like two female ray-fishes he earlier had studied in Copenhagen ([1], p. 585). He had "no longer doubts that the [so-called] testicles of females are analogous to ovaries," and stated this will "correct this error by which people believe that the genitals of females are analogous to the genitals of men". Until then ovaries of mammals, women included, had been categorized as "female testicles". Since then they were categorized as analogous with organs of egg laying animals and named accordingly.

Steno examined the shark's internal genitals by making moulds of the oviducts in order to study the mucosa:

(...) a parallel structure of nipples appeared most elegantly for the same reason that shapeless wax poured in plaster moulds, when hardened, represents the shape of the mould once the plaster has been removed. ([1], p. 600, figs. III and IIII).

The moulding technique must have been known to Steno from his father's goldsmith's workshop ([29], p. 132). He later used what Stephen J. Gould called 'the principle of moulding' to determine the relative age of interacting geological items in the Prodromus [30].

Steno converted to Catholicism in November 1667 during an active period of research ([1], p. 220).

The book in three parts, the Specimen of Elements of Myology, covers pioneering research based on observations and reflections on issues now framed as biology and geology. His conjectures had their origin in incidental observations that in a Galilean sense made further observations measurable for testing in models.

Jens Morten Hansen has assessed the criteria Steno used to obtain certainty on conclusions on unobservable events in the past [31].

Raphaële Andrault [32] categorized Steno's method in research on muscle as the hypothetico-deductive method.

These are opinions on which I can only agree based on my earlier assessment ([39], pp. 96-97). Moreover, in Galileo's Discorso (1612) and in Steno's Canis carchariae dissectum caput of 1667 (Conjectura 1: [1]), are found the same uncommon marker of the method:

verisimile in Galileo: 'Il discorso, e l'esperienza hanno veramente tanto del probabile, e del verisimile, che maraviglia non sarebbe, se molti persusi da una certa prima apparenza, gli prestassero il loro assenso: tuttavia io credo di potere scoprire, come non mancano di fallacia. / And truly the reasoning and the experiment have so much probability and verisimilitude that it would be no wonder if many, persuaded by a first appearance of [truth], should lend their assent to this; yet I can believe I can show no lack of fallacies' ([35], p. 80).

verosimiliter in Steno: 'Cum itaqve in duriori terra nulla de novo produci videantur corpora; cum terra mollior eadem corpora multis in locis verosimiliter destruat: non sine ratione suspicari licebit, terram, unde animalium partibus similia corpora eruuntur, corpora illa hodie non producere. /Thus, since no bodies seem to be produced anew in harder soil, and since in many regions softer soil probably [as translated by Alex J. Pollock (1969)] destroys these bodies, we may suspect not without reason, that soil from which bodies resembling parts of animals are dug does not produce these bodies today' ([1], p. 720).

The words emphasized are from the same stem, verisimilar/verisimilitude, as in English being key words in the analysis of the hypothetico-deductive system axiomatized by Karl R. Popper in Conjectures and Refutations from analysis of studies by authors in Antiquity and Early Modern science, not the least in works by Galileo ([33], pp. 100,.).

In the Canis manuscript evidenter is crossed out and replaced by verosimiliter in Steno's hand (Fig. 6). Verosimiliter is found only this single time in Steno's printed works. In his CHAOS-Manuscript ([4], pp. 404, 419, 423, 440), verisimile is found four times in a long excerpt from Pierre Gassendi's Animadversiones in Decimvm Librvm Diogenis Laertii, qvi est de Vita, Moribus, Placitisque Epicvri, ..., published in Lyon in 1649. Could it be that Steno came over the word again in Galileo's text as quoted above during proof-reading the Canis?

\section{PRODROMUS}

Published two years after the Specimen of Elements of Myology, the Prodromus de solido intra Solidum contained another time-related model of transformation of solids visualizing

how six distinct aspects of Tuscany may be inferred from its present appearance, at the same time serve to make more intelligible those things that we have stated about the strata of the earth. ([1], p. 822-825)

Steno's well-known illustration of the geological history of Tuscany in six schematic cross sections of landscapes was later used by Steno's student Holger Jacobæus when, as a professor at Copenhagen University, he fulfilled Steno's wish "to make more intelligible" such transformations (Fig. 7). Jacobæus' sketch and notes for geological lectures were published by Axel Garboe (1948) 
[34]. They are among the few recordings of Steno's geology in his homeland, Denmark before the $19^{\text {th }}$ century.

In the Prodromus a chapter on the growth of crystals by accretion of solid material to the surface is another description of a time-related solid transformation:

A crystal grows while new crystalline material is added to the exterior planes of the already formed crystal, so that there is no room at all here for the opinion of those who assert that crystals grow vegetatively.

The external fluid receives crystalline material from the substance of the harder stratum, so that rocks of different types, emitting different fluids, produce crystals of different colours ([1], pp. 794-796).

A lengthy digression concerns the division of the water space in the living organism in outer compartments, this means the space with direct connection to the surface of the body, and an inner compartment, subdivided into a common division for the whole body and inner divisions specific to each part (organs, mus-

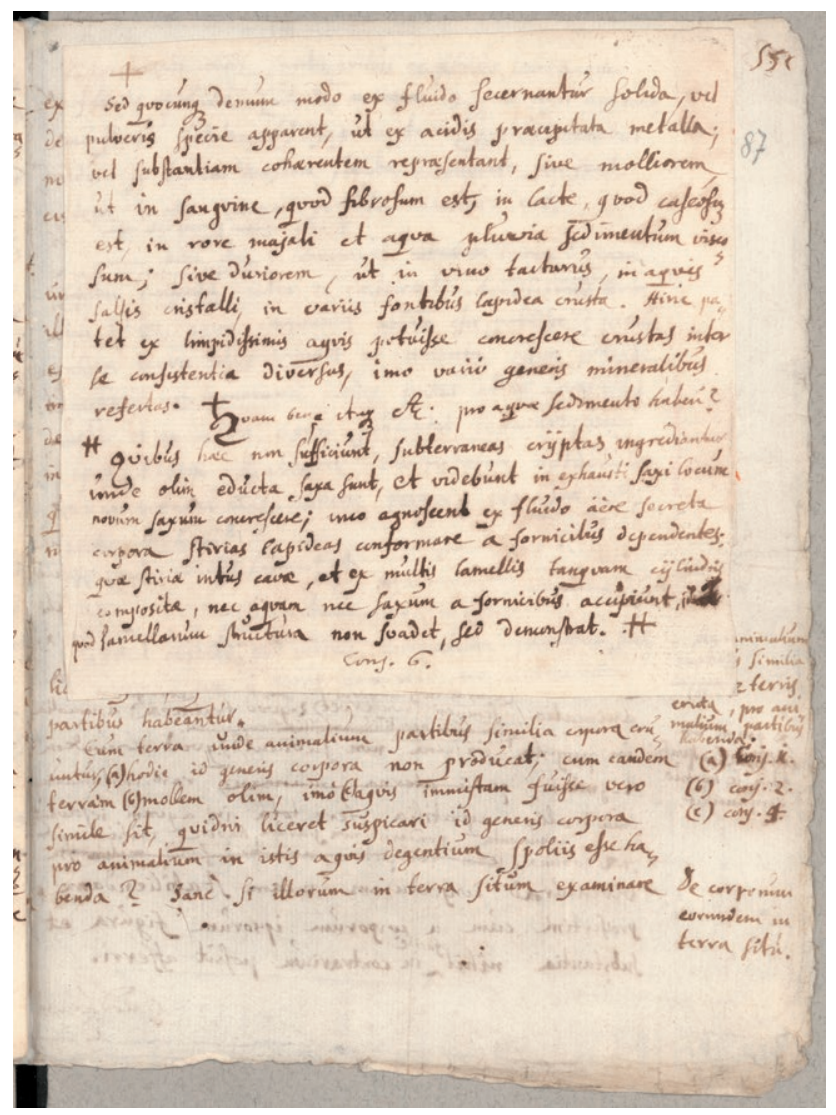

Figure 6. Page 81 from the Canis manuscript, part of Elementorum Myologiae Specimen, Royal National Library, Copenhagen, open access from www.kb.dk. Corrections and added subheadings in the margin are in Steno's handwriting (see also Fig. 5). cles etc.) ([1], p. 779-78). Steno makes a practical, clinical point: "Most of the worms and stones inside our body are produced in the external fluid". He may even have developed an interest in studying crystal growth as a physician who sought to know how gallstones and bladder stones grow in what he called the external fluid.

After hurriedly completing the Prodromus, Steno traveled through Europe which included a visit to Innsbruck where he was asked by Anna de' Medici, the Archduchess of Austria and sister to Ferdinand II, to make an anatomical examination in a calf born with gross skull and brain malformations from hydrocephalus. Nonetheless as said, the animal had been able to sense. He concluded that hydrocephalus was caused by water held back by a cyst located 'at the root of the nostrils' near what is now called the optic chiasm. The cyst obstructed the passage of liquid between the brain's inner cavities. Such a 'foramen' was described in 1783 and named after the Scottish surgeon investigator, Alexander Monro. Among several conclusions Steno assumed that the malformation was hardly caused as commonly

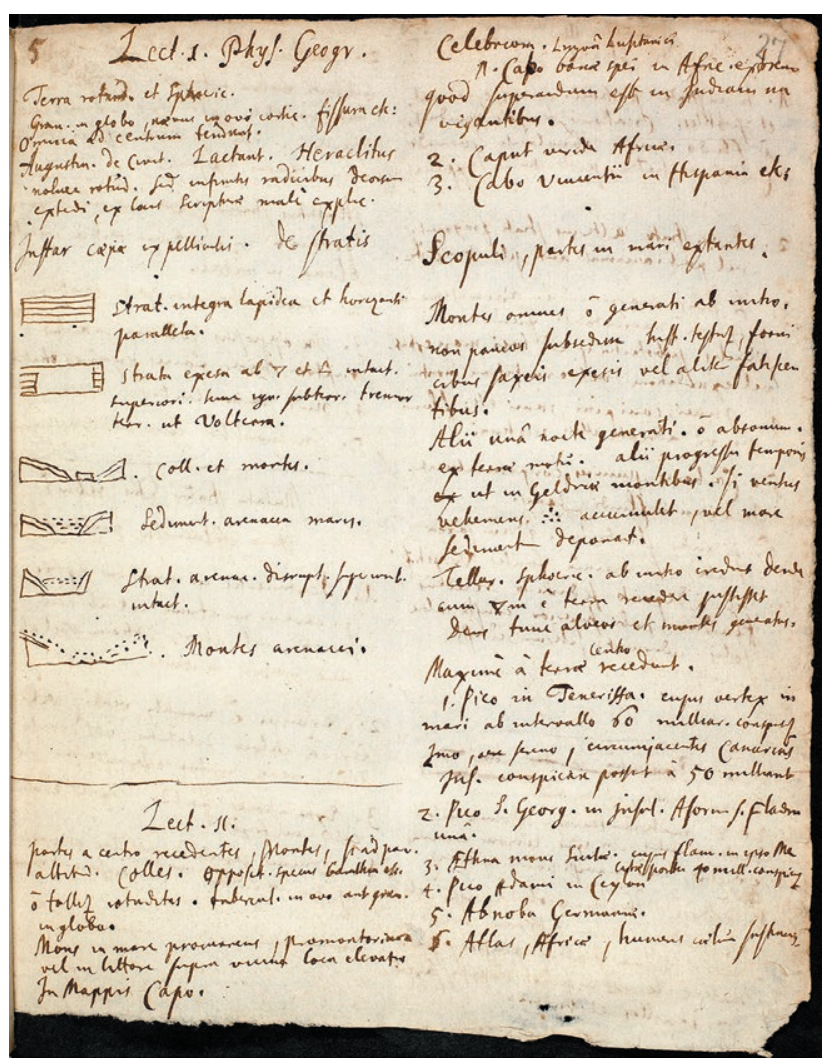

Figure 7. Steno's model of Tuscany drawn by his disciple Holger Jacobæus (1650-1701), professor at the University of Copenhagen since 1674, from his Lecture 1(Royal Danish Library, Manuscript collection, Thott $11084^{0}$ ) [34]. 
thought by visual imaginations in the mother - a cow. From details, the obstructing tumour may have been a craniopharyngioma as has been described in cattle and in humans [35].

When back in Copenhagen for two years, Steno gave an opening lecture, the Proemium ... on January 28, 1673, in the re-opened Anatomical Theatre in Copenhagen. It was ostentatiously announced by his former teacher, professor Thomas Bartholin:

By the clemency of our very majestic King and Lord CHRISTIAN V, Father of the Fatherland, was called back to his homeland the most celebrated gentleman NIELS STENSEN, the new Democritus of the century. He consoles the hope of scholars, he will witness to the Fatherland that the fame obtained in the learned world by famous inventions and writings which respire bitten off nails, is not his private but public possession. In that intention, he started without envy, when scarcely he recently had set his foot in his native town, for the benefit of Asclepius' youngsters with lucky and ready hand to search the viscera of animals, in order to make visible every thing that was hidden. During the autumn of last year, though the weather was not enough favourable, he had publicly and privately dissected a human corps, two bears, a reindeer, a goat, hares, a cat, mice, a hedgehog, a squirrel, a dormouse, a monkey and other animals. Observations thereof I have put in the Acta Medica et Philosophica which are being printed. Not without exercise should pass the first months of the new year during these holidays, therefore he decided out of love for science and young people of the country, with the approval of the authorities and the agreement of the patron of the Academy Sir PETER REEDZ, Knight and the King's Great Counsellor to make in a humane corpse of female sex the experiment of his ability and doctrine in the Anatomical Theatre to the glory of God, the proficiency of Nature and the profit of the medical world. ([1], pp. 849-852)

More on body liquids was expressed on February 2, 1673 during the subsequent public dissections over a week as, so to say, 'stenographed' by Holger Jacobæus, his student:

(It) is explained by the example of the building up of tartar on the teeth. There, indeed, the saliva clinging to the teeth gradually loses its more fluid parts, while thicker parts condense with time and harden. Or, to put forward a more common example, salt condenses in proportion to the evaporation of water from salt water [...] both in the gallbladder, in the kidneys, in the small glands either of the tongue or of the rest of the body, and in the skin of gouty people, small stones condense in proportion to the evaporation of a thinner fluid ([1], pp. 865-866)

Just two months later Steno writes about his situation in Copenhagen to his friend, the mathematician
Vincenzo Viviani, in Florence. The newly recovered autograph letter is dated 18 April 1673 (Fig. 8):

The reason of delaying writing to you [...] was the hope of hearing perhaps tomorrow the outcome regarding my position, that even now is still in doubt. [...] If I live to the Holy year [1675], I hope to go to ask permission to come to the service of the Lord Prince [Ferdinando], as His Serene Majesty [Cosimo III] has very kindly told me that he would like me to serve him. ${ }^{8}$

What an agony: few months after the Proemium lecture left in doubt of his situation with a wish to return to Florence. Steno continued giving dissections in small groups assisted by Holger Jacobaeus until he received royal permission to leave Copenhagen with a passport signed by Count Griffenfeld. After few months preparation in Florence he became a priest. Three years later he was called as Bishop in Northern Germany where he died in 1686.

\section{THE GALILEAN INSPIRATION}

Steno, possibly inspired by his teacher Ole Borch, wrote on solvents and solutes in the Chaos Manuscript in 1659:

Beer from well water contains many impurities which overload the vessels of the mesentery etc., for in a barrel of rainwater a handful and more of dissolved earth is found. Hop has also its kinds of sediment. For if you distil beer, on the bottom you will find something like a sticky syrup ([4], pp. 321-322).

On the same theme he gave the following brief remark without any implications:

8 ‘... Mi disse ieri un grand ministro del Re, che dimane voleva parlarmi a lungo e vedere cosa si potrebbe fare. Ma Dio sa quel che ne seguirà. Ed esso Dio sia benedetto comunque sortirà. Mentre, col farsi la di lui volontà tutto sarà per bene di chi lo teme. Tanto che non si vede più stabile dimora, che per adesso, non posso pensare né al Sig. re Lorenzo, né al Sig. re Giovan Battista. Iddio disponga ogni cosa con essi, e meco, secondo la sua Santa volontà. Il Sig. re Bartholino è Professore il Sig. re Scavenio è Procuratore Generale, il Sig. re Langio Giudice Provinciale. Se vivo all'anno Santo, spero venir da loro, principalmente de se S. A. Ser. ma gradisse che io per venire ad servizio del Sig. re Principe domandi licenza per quel tempo, che $\mathrm{S}$. A. Ser. ma vorrà servirsi di me, conforme ella midesima con somma benevolenza m'ha detto il suo volere .... Royal Danish Library, Manuscript Collection, Shelf Mark: Acc. $2019 / 11$. The letter was offered for sale on google by sophiararebooks. com in 2018 and was found in a search for the review in Journal des Sçavants of the $3^{\text {rd }}$ edition of Steno's Elementorum Myologiae Specimen, 1711. The letter was donated to the Royal National Library in Copenhagen 2019. 


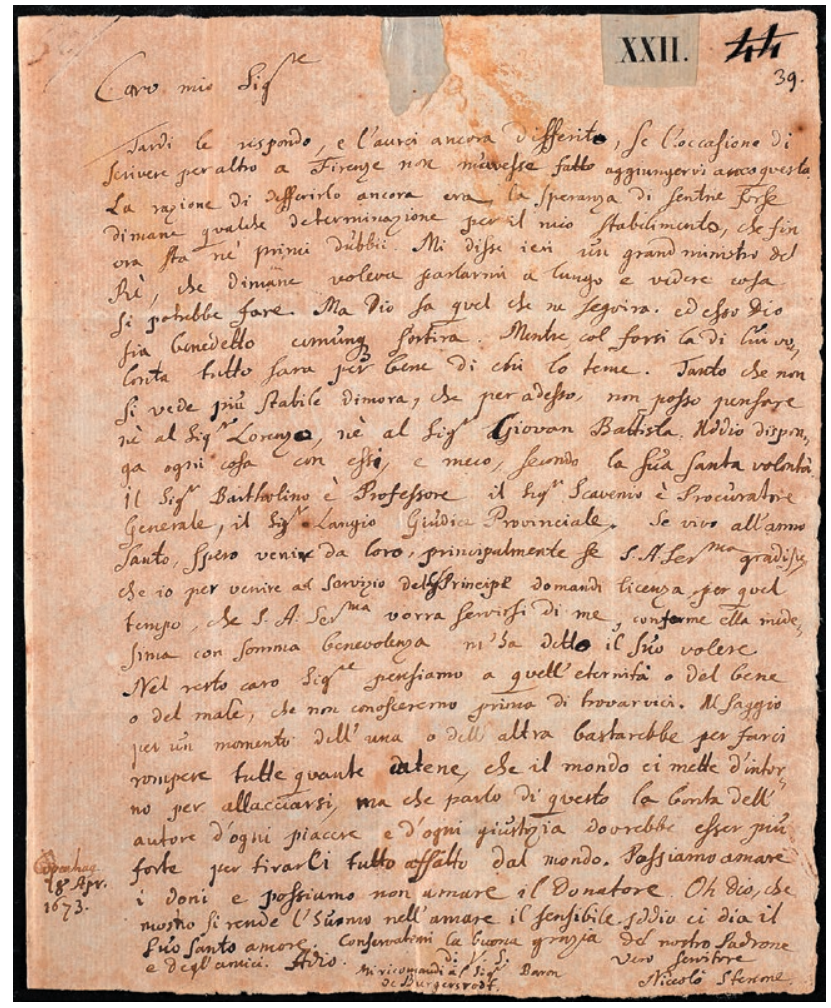

Figure 8. Steno's letter to Vincenzo Viviani, Shelf Mark: Acc. 2019/11 Royal Danish Library, the Manuscript Collection.

All sand has been water and can be changed into water. (4, p. 391)

As mentioned in the beginning Steno wrote an excerpt from Galileo's Sidereus Nuncius, ([4], p. 301-302) and eleven years later payed tribute to the late master when in the Prodromus he referred to "Magni Galilei" on liquid matters:

We are taught, moreover, by the most substantial proofs of the great Galileo that heavier bodies of this kind can remain on the top surface of a fluid while one of their surfaces is in immediate contact with an overlying and lighter fluid of another sort; the aqueous nature of one of the fluids referred to is shown by the material of the strata that is deposited from the said fluid ([1], p. 802/note 105).

Read in context, Steno's compliment was not as usually held just a tribute; nor is it a declaration of solidarity. Rather he demonstrates a cognition of shared interest with the late Galileo on the rules for the interaction of solids and liquids in contact as described by Galileo in the Discourse on Bodies in Water - Discorso intorno alle cose, che stanno in su l'acqua e che in quella si muovono (1612):
In water, there descend, even those particles that muddy it, whose smallness is such that they are not seen except in many hundreds together' ([5], p. 170).

Galileo concludes:

Nothing more need be said on this that has been said already; namely, that it is not [as held by Aristotle] resistance to simple division, which does not exist in water or air, but heaviness of the medium that must be compared with the heaviness of the moveable. That being greater in the medium, the moveable will not descend in it, nor even submerge entirely, since in the place it occupies in the water there cannot rest a body weighing less than as much water; but if the moveable shall be heavier, it will descend to the bottom, to occupy place where it is more suitable to nature for it to rest than some less heavy body. And that is the single, true, proper and absolute cause of swimming above or going to the bottom, so that no other [cause] plays a part in it ([35], p. 193)

Steno refers to Galileo's principles on solutes and solids in contact, and he must have known them when he described the transformation of originally horizontal sediments at the sea-bed as well as the growth of crystals by layering to the surface.

Steno should be remembered not just for the structures he described but for the descriptions of what happens to them, concepts that changed anatomy, physiology and geology into teaching of dynamic processes, and as a housekeeper of science $([13,36])^{9}$. He did not attribute effects to imaginary effectors in the living organism like animal spirits, or a formative ability, vis formans, of rocks. Steno remained courteous when meeting in Rome P. Athanasius Kircher who excessed on such in his newly published work, Mundus subterraneus, with tales on bones of dragons, possibly, as has been suggested, fossils of extinct species. ${ }^{10}$

Steno was self-critical and respectful in his critique of the ancients. He emphasized that his knowledge, like theirs, would be revised. But Steno readily downed unfounded conceptions by Descartes on brain and muscles and by contemporary writers, and even one of his

\footnotetext{
9 'Mr. Willis gives us a quite peculiar system. He accommodates common sense in the corpus striatum, imagination in the corpus callosum and memory in the cortex or in the greyish substance which envelopes the white one. ... How can he be so assured to make us believe that these operations occur in the bodies which he destines to them?' ([1], p. 608). See examples on Steno's scrutinty in cleaning up in brain research [37]. See also, Wilson (1961) on Steno's encounter with Croone at Montpellier 1666 [14].

${ }^{10}$ Steno remained courteous when meeting in Rome P. Athanasius Kircher who excessed on such effectors in his newly published work, Mundus subterraneus, with tales on bones and dragons, possibly, as has been suggested, fossil remains of extinct species: web address: http:// christianlatin.blogspot.com/2008/08/athanasius-kirchers-natural-history-of.html
} 
mentor Thomas Bartholin's favorite developments: since the nutritive chyle, the lymphatic drainage from the intestines, bypasses the liver as described by Pecquet, that organ had been "dethroned" from blood production; then Bartholin entrusted the heart with the task, on which, as quoted earlier, Steno bluntly stated, 'the heart is actually a muscle'.

Steno in research drew on inspiration from Galileo. He distinguished between what is not known as an entity and the little we know or can see, as expressed in his well-known saying:

Beautiful is what we see, more beautiful what we know, but by far the most beautiful is what we do not know ([1], p. 857).

\section{REFERENCES}

[1] T. Kardel, P. Maquet, Nicolaus Steno, Biography and Original Papers of a 17th Century Scientist, 2018, $2^{\text {nd }}$ edition, Heidelberg, Springer. https://doi. org/10.1007/978-3-662-55047-2_4 [paginations of the two editions differ].

[2] N. Stensen/Nicolai Stenonis, Elementorum Myologiae Specimen, seu Musculi Descriptio Geometrica, 1667, Florence, Stella (English translation: [1], pp. 649739).

[3] N. Stensen/Nicolai Stenonis, 1669, Prodromus De Solido intra Solidum, Florence, Stella (English translation: [1], pp. 763-825).

[4] A. Ziggelaar, Niels Stensen's Chaos-manuscript, Acta Hist. Sci. Nat. Med., 1997, vol. 44 [Open access www.kb.dk].

[5] G. Galileo, 1612. Discorso al Serenissimo Don Cosimo II...Intorno alle cose, che Stanno in su l'acqua, o che in quella si muovono. "Discourse on Bodies in Water", Introduction and translation by S. Drake, Cause, Experiment and Science: a Galilean dialogue, University of Chicago Press, 1981.

[6] H. Moe, Nicolaus Steno, an illustrated biography, 1994, Copenhagen, Rhodos, 100 p. [Danish edition 1988].

[7] J.-F. Vincent, C. Perrot, Johannes Van Horne and Marten Sagemolen's myology. Four volumes of anatomical drawings of the Golden Age rediscovered at the Bibliothèque interuniversitaire de santé (Paris). 31 Aug. 2016 [E-paper:http://www.biusante.parisdescartes.fr/ressources/pdf/van-horne_en.pdf ].

[8] R. Des Cartes, De Homine figuris et latinitate donatus a Florentio Schuyl, Leiden, Moyardus and Leffen, 1662.
[9] T. Kardel, 'The influence of Swammerdam', Steno on Muscles, Trans. Am. Philos. Soc., 1994, 84, pp. 16-17.

[10] T. Kardel, on Graindorge letter, Steno and the Philosophers (Eds.: R. Andrault, M. Lærke), Leiden, Brill, 2018, p. 145, note 27. https://doi. org/10.1163/9789004360655_008.

[11] M. A. Nayler, The insoluble Problem, Thesis University of Melbourne, Australia, 1993. M. A. Nayler, "Introduction", in W. Croone, "On the Reason of the Movement of Muscles, Philadelphia", Trans. Am. Philos. Soc., 2000, Part 90, pp. 2-53.

[12] W. Croone, "An Hypothesis of the Structure of a Muscle, and the Reasons of its Contraction; read in the Surgeons Theatre, Anno 1674,1675", Philosophical Collections of the Royal Society of London, 2, 1681, pp. 22-25.

[13] L. G. Wilson, Notes Rec. Roy. Soc. 1961, 16, p. 168. https://doi.org/10.1098/rsnr.1961.0036.

[14] Transactions of the Royal Society of London, 1667/68, 2, pp. 627-628.

[15] T. Kardel, "Willis and Steno on Muscles. Rediscovery of a 17 th-century biological theory". J Hist Neurosci 1996, 5, pp. 100-7. https://doi. org/10.1080/09647049609525657

[16] J. B. Andersen, Thomas Bartholin, Logen og anatomen. FADL's Forlag, Copenhagen, 2017.

[17] T. Kardel, "Steno on Muscles", Trans. Am. Philos. Soc., 1994, Part 84, pp. 25-42.

[18] T. Kardel, Stensen Notizie, 1997, 434 (supplement), pp. 7-19.

[19] T. Kardel, Acta Anat., 1997, 159, pp. 61-70. PMID: 9522899

[20] G. A. Borelli, On the Motion of Animals, translated by P. Maquet, Springer, Berlin/Heidelberg, 1989.

[21] P. W. Brand, R. W. Beach, D. E. Thompson, J. Hand Surg., 1981, 6, pp. 209-219. https://DOI: 10.1016/ s0363-5023(81)80072-x

[22] T. Kardel, J. Biomech., 1990, 23, pp. 953-65. https:// doi.org/10.1016/0021-9290(90)90310-y

[23] R. S. Chow, M. K. Medri, D. C. Martin, R. N. Leekam, A. M. Agur, N. H. McKee, Eur. J. Appl. Physiol., 2000, 82, pp. 236-244. https://doi. org/10.1007/s004210050677

[24] G. P. Pappas, D. S. Asakawa, S. L. Delp, F. E. Zajac, J. E. Drace, J. Appl. Physiol., 2002, 92, pp. 2381-2389. https://doi: 10.1152/japplphysiol.00843.2001

[25] K.-T. Hsu, in "The Revolution in Geology from the Renaissance to the Enlightenment" (Ed.: G. D. Rosenberg), Geol. Soc. Am. Mem., 2009, 203, pp. 93-106.

[26] M. Brasier, Philos. Trans. A Math. Phys. Eng. Sci., 2015. https://doi.org/10.1098/rsta.2014.0254 
[27] T. Yamada, in "The Revolution in Geology from the Renaissance to the Enlightenment" (Ed.: G. D. Rosenberg), Geol. Soc. Am. Memoirs, 2009, 203, pp. 107-126. https://doi.org/10.1130/978-0-8137-1203-1203.0.107

[28] A. Cutler, The seashell on the mountaintop, Dutton, New York, 2003.

[29] T. Kardel, (Ed.: G. D. Rosenberg), Geol. Soc. Am. Mem., 2009, 203, pp. 127-134. https://doi. org/10.1130/978-0-8137-1203-1-203.0.127

[30] S.J. Gould, The titular Bishop of Titiopolis, Nat. Hist., 1981, 90, pp. 20-24.

[31] J.M. Hansen, in "The Revolution in Geology from the Renaissance to the Enlightenment" (Ed.: G. D. Rosenberg), Geol. Soc. Am. Mem., 2009, 203, pp. 159-178.

[32] R. Andrault, Early Sci. Med., 2010, 15, pp. 505-536. https://www.jstor.org/stable/20787426

[33] Karl R. Popper, Conjectures and Refutations, the Growth of Scientific Knowledge, 1989, Routledge, London and New York, pp. $100 \mathrm{ff}$.

[34] A. Garboe, Niels Stensens (Stenos) geologiske arbejder skcebne, 1948, Copenhagen, Danmarks Geologiske Undersøgelse, with English summary.

[35] T. Kardel, J. Hist. Neurosci., 1993, 2, pp. 171-202, https://doi.org/10.1080/09647049309525566. 